\title{
Characterization of Constitutively Activating Eel Follicle-Stimulating Hormone Receptor
}

\author{
Jeong-Soo Kim ${ }^{1}$, Munkhzaya Byambaragchaa ${ }^{1}$ and Kwan-Sik Min ${ }^{1,2, *}$ \\ ${ }^{1}$ Animal Biotechnology, Graduate School of Future Convergence Technology, Hankyong National University, Anseong \\ 17579, Korea \\ ${ }^{2}$ Department of Animal Life Science, Institute of Genetic Engineering, Hankyong National University, Anseong 17579, Korea
}

Received September 23, 2019

Revised November 5, 2019

Accepted November 21, 2019

*Correspondence

Kwan-Sik Min

E-mail:ksmin@hknu.ac.kr

ORCID

https://orcid.org/0000-0002-5451-3085

\begin{abstract}
This study aimed to investigate the function of the constitutively activating mutation D540G on eel FSHR activity by in vitro functional studies. Sitedirected mutagenesis was carried out to generate the D-to-G mutation at position 540 of the pcDNA3-eel FSHR construct. Vectors expressing either wild type or mutant receptor were transfected into Chinese hamster ovary (CHO-K1) cells. The functional characteristics of both the wild type and mutant receptors were analyzed by a cAMP assay. cAMP accumulation was highly increased in cells transfected with the D540G mutant receptor in a dose-dependent manner. Of note, basal cAMP levels were remarkably increased ( 13.1-fold) with expression of this mutant when compared to wild type receptor. These findings suggest that the D540G mutation in the eel FSHR may contribute to ovulation during eel sex maturation as well as play a pivotal role in inducing FSHR activity.
\end{abstract}

Keywords: cAMP, constitutive activation, eel, FSH receptor

\section{INTRODUCTION}

Follicle-stimulating hormone (FSH) is the specific central glycoprotein hormone of mammalian reproduction, and is necessary for sex maturation at puberty during the fertile phase (Simoni and Nieschlag, 1995). The FSH receptor (FSHR) is a member of the seven-transmembrane domain or G protein-coupled receptor (GPCR) superfamily of cell surface receptors (Kim et al., 2018). FSHR is mainly synthesized in granulosa and Sertoli cells, and moves to the membrane surface. Constitutively activating mutations in the FSHR gene were found to localize in an essential region of the transmembrane domain, which is highly conserved among FSHRs, and within FSHRs across different species (Simoni et al., 1997). Previous work by others has shown that transmenbrane domains $\mathrm{V}$ and VI of the male FSHR bearing a D567G mutation maintain constitutive activity in such a constrained state that there is no appreciable effect on basal cAMP levels (Gromoll et al., 1996). Furthermore, a Ile160Thr mutation of the FSHR extracellular domain was reported to drastically reduce binding of iodinated human FSH in COS-7 cells. This resulted in a decrease of cAMP to $10 \%$ of the maximum value observed in wild type cells in response to exogenous FSH binding (Beau et al., 1998). Similarly, a cell line harboring Arg573Cys mutation in exon 10, which encodes the third loop, produced only about $30 \%$ of wild type cAMP levels (Tapanaine et al., 1997).

A novel FSH receptor mutation was identified in a patient with primary ovarian failure and infertility by whole 
exome sequencing (Bramble et al., 2016). A novel homozygous mutation, $\mathrm{C} 175 \mathrm{~T}$, was detected in a Chinese woman with primary ovarian insufficiency (Liu et al., 2017). The polymorphism genotypes of FSHR G919A in premature ovarian failure of Iranian women may be associated with diminished ovarian reserve (Ghezelayagh et al., 2018). Two female siblings of Indian descent were diagnosed with primary ovarian failure and hypergonadotropic hypogonadism associated with mutations of the FSH receptor (T1253G; G1255A) (Katari et al., 2015).

Recent work from our group has focused on elucidating the function and role of glycoprotein hormones and their receptors in the Japanese eel (Kim et al., 2016a,b; Kim et al., 2018; 2019; Byambaragchaa et al., 2018a,b). To determine the mechanisms underlying eel reproduction, we investigated the activity of eelFSHR containing a mutation in the transmembrane $\mathrm{Vl}$ domain. To our knowledge, this is the first report of constitutive activation of the eelFSHR (D540G) mutation and its effects on basic cAMP response.

\section{MATERIALS AND METHODS}

\section{Materials}

The mammalian expression vector pCDNA3, FreeStyle CHO-S suspension cells, and Lipofectamine-2000 were bought from Invitrogen Corporation (Carlsbad, CA, USA). The cloning vector pGEMTeasy was bought from Promega (Madison, WI, USA). cAMP HTRF assay kit was purchased from Cisbio (Codolet, France). Primary antibody coating of 96-well plate was conducted with 5A11 monoclonal antibody as previously reported (Kim et al., 2016). Polymerase chain reaction (PCR) reagents were from Takara (Shiga, Japan). The QIAprep-Spin plasmid kit was purchased from Qiagen. Inc. (Hilden, Germany). Fetal bovine serum was from Hyclone laboratories (Logan, UT, USA). Centriplus Centrifugal Filter Devices were purchased from Amicon Bio separations (Billerica, MA, USA). All other reagents used were from Sigma-Aldrich (St. Louis, MO, USA) and Wako Pure Chemicals (Osaka, Japan).

\section{Site-directed mutagenesis and vector construction}

To introduce eel FSHR point mutations to generate a constitutive mutant, an overlap extension PCR strategy was used as previously reported (Min et al., 2004). Two different sets of PCRs were performed. The newly synthesized full-length PCR products were eluted and cloned into an pGEMTeasy vector and transformed into $\mathrm{DH} 5 \alpha$ competent cells. Plasmids were isolated and sequenced (Genotech, Korea). cDNAs encoding both wild type and mutant eel FSHR were digested with Eco RI and Xho I, and ligated into pcDNA3 as previously reported (Min et al., 2004). Plasmids were then purified and confirmed by restriction digestion analysis to ensure that the correct mutant PCR production had been inserted (designated as pcDNA3-eel FSHR-D540G).

\section{Transient transfection and production of rec-eelFSH protein}

Recombinant eel FSH protein was produced in $\mathrm{CHO}-\mathrm{S}$ cells using the liposome transfection method as previously described (Byambaragchaa et al., 2018). Supernatants were collected and frozen at $-80^{\circ} \mathrm{C}$. The samples were concentrated by freeze-drying and mixed with PBS. The concentration of recombinant-protein was analyzed by enzyme-linked immunosorbent assay (ELISA) as previously reported (Byambaragchaa et al., 2018).

\section{cAMP assay}

Measurement of cAMP accumulation in CHO-K1 cells expressing wild type and mutant eel FSHR receptors was performed using cAMP Dynamic 2 competitive immunoassay kits (Cisbio Bioassays, Codolet, France) as described previously (Lee et al., 2017). These method uses a competitive immunoassay between native cAMP produced by cells and cAMP labeled with the dye $\mathrm{d} 2$. The specific signal-Delta $\mathrm{F}$ (energy transfer) is inversely proportional to the concentration of cAMP in the standard or sample. Results are calculated from the $665 \mathrm{~nm} / 620 \mathrm{~nm}$ ratio and expressed as Delta F \% (cAMP inhibition). cAMP concentrations were calculated from Delta F\% values using GraphPad Prism software (GraphPad, Inc., La Jolla, CA, USA).

\section{Data analysis}

The Multalin interface-multiple sequence alignment tool was used for sequence analysis and comparisons; GraphPad Prism 6.0 (GraphPad, Inc, CA) and Grafit 5.0 (Erithacus Software Limited, Surrey, UK) was used for cAMP $\mathrm{EC}_{50}$ value and stimulation curve analysis. Each curve was drawn using data from at least three independent experiments. 


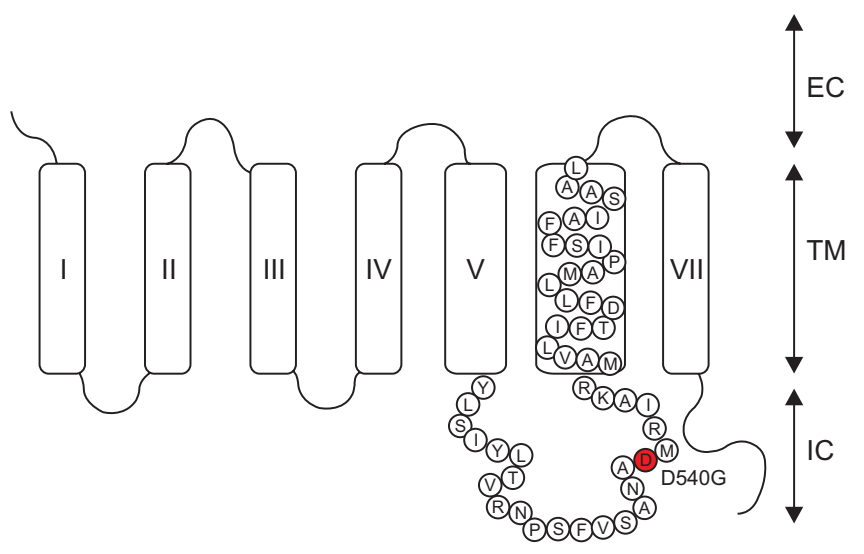

Fig. 1. FSHR structure and location of the activating mutation. The extracellular domain (EC) consists of several regions, while the transmembrane domain (TM) consists of seven hydrophobic segments spanning the cell membrane. These segments are connected by intra- and extracellular loops. The activating (D540G) mutation is indicated and lies within intracellular domain (IC) 3 .

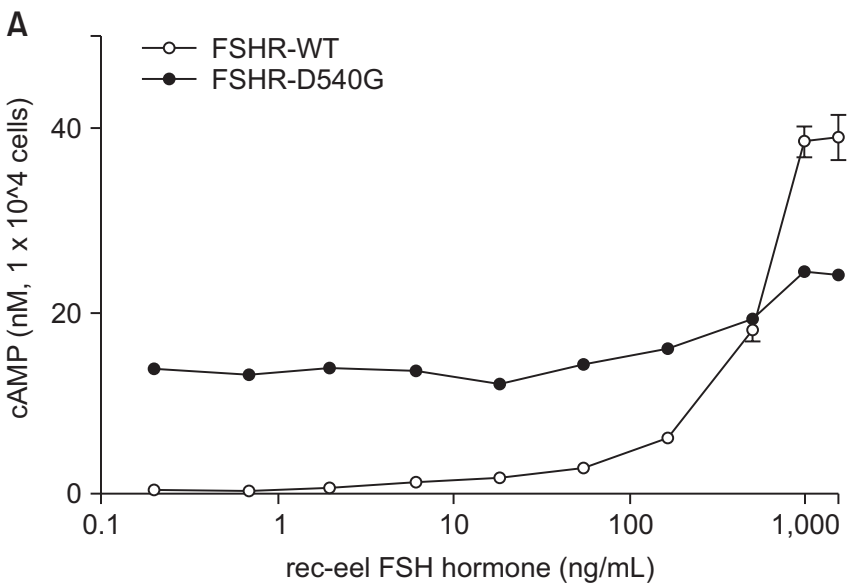

\section{RESULTS}

The mutation (D540G) is located at the C-terminal region of the third intracytoplasmic loop (IC) amino acid 540 of the receptor, and work by others has shown its involvement in a case of pseudoprecocious puberty (Laue et al., 1995) (Fig. 1). This region of the receptor is highly conserved among glycoprotein hormone receptors. CHO$\mathrm{K} 1$ cells transiently transfected with the mutant receptor produced cAMP at basal levels that were consistently higher than those produced by the wild type receptor in the absence of eel FSH agonist. When $2.5 \mu \mathrm{g}$ of plasmid DNA encoding the wild type receptor was transfected into cells, cAMP levels were increased in a dose-dependent manner. In contrast, transfection of the constitutively active mutant receptor increased cAMP levels to values much higher than those of cells expressing the wild type receptor, even in the absence of FSH stimulation. cAMP levels in cells expressing the D540G mutation reached

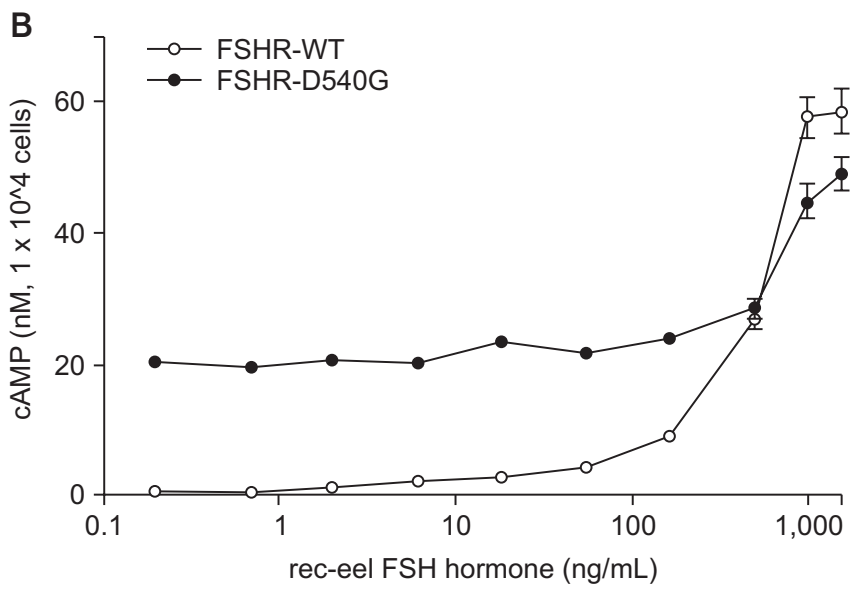

Fig. 2. Basal and FSH-stimulated CAMP production by CHO-K1 cells transiently transfected with wild type (O) or D540G mutated ( $\bullet$ ) FSH receptor constructs. Left (A): transfection with $2.5 \mu \mathrm{g}$ DNA plasmid. Right (B): transfected with $5 \mu \mathrm{g}$ DNA plasmid. cAMP production in response to increasing concentrations of recombinant-eelFSH. Results are expressed as the mean \pm SEM of two individual experiments performed in duplicate. Basal CAMP was measured by transfecting the cells with pcDNA3 vectors.

Table 1. Bioactivity of eelFSH receptors in cells expressing activating receptor mutants

\begin{tabular}{|c|c|c|c|}
\hline \multirow{2}{*}{ eelFSH receptors } & \multicolumn{3}{|c|}{ cAMP responses } \\
\hline & Basal (nM/10 cells) & $\mathrm{EC}_{50}(\mathrm{ng})$ & $\operatorname{Rmax}\left(\mathrm{nM} / 10^{4}\right.$ cells) \\
\hline eelFSHR-WT (2.5 ug) & $1.0 \pm 0.3(1$-fold $)$ & $538.5(100 \%)$ & $40.3 \pm 2.8(100 \%)$ \\
\hline eelFSHR-D540G (2.5 ug) & $13.6 \pm 0.5(13.1-$ fold $)$ & $555.5(15 \%)$ & $27.6 \pm 4.3(68.5 \%)$ \\
\hline eelFSHR-WT (5 ug) & $1.0 \pm 0.2(19.1-$ fold $)$ & $543.8(100 \%)$ & $61.3 \pm 4.7(100 \%)$ \\
\hline eelFSHR-D540G (5 ug) & $19.6 \pm 2.3$ (19.6-fold) & $685.0(20 \%)$ & $50.8 \pm 3.5(82.9 \%)$ \\
\hline
\end{tabular}

Values are the means \pm SEM of triplicate experiments. $\mathrm{EC}_{50}$ values were determine determined from the concentration-response curves from in vitro bioassays. 
concentrations 13.1-times higher than wild type. However, the maximal cAMP level was $68.5 \%$ relative to wild type (Fig. 2). Next, we analyzed the induction of cAMP production using $5 \mu \mathrm{g}$ plasmid DNA for transfection. In these experiments, cAMP level were increased to an even greater extent (19.6-fold) in the absence of recombinanteel FSH than that by the wild type cells. Maximal cAMP levels were also increased in the receptor cells transfected with $5 \mu \mathrm{g}$ plasmid DNA, but approximately $83 \%$ compared to that in wild type (Table 1).

\section{DISCUSSION}

We characterized one constitutive activating mutation, D540G, in the eel FSHR, which has been previously reported in FSHR (Fig. 1). The molecular function of the constitutively activating D540G FSHR mutation is still unknown. To the best of our knowledge, this is the first report in which constitutively activating eel FSH receptor results in highly increased cAMP production. We reported that rat FSHR indicated highly basal cAMP level, even in the absence of a ligand (Min et al., 1996). Some studies suggest that gonadotropic hormones, particularly FSH, influences the development of ovarian tumors (Fragoso et al., 1998; Bas et al., 2009). These results indicate that tumors originating from granulosa cells contain FSHRs and that tumorigenesis is affected by FSH and by activation of FSHR-mediated signaling pathways (Stouffer et al., 1984; Nakano et al., 1989; Fragoso et al., 1998). Activating mutation in the FSHR was firstly described in the hypophysectomized 28-year-old male that was unexpectedly fertile (Gromoll et al., 1995b). Screening of the FSHR gene led to the characterization of a point mutation in exon 10, D567G, in the third transmembrane loop of the receptor protein. Basal cAMP levels were increased in COS-7 cells harboring this mutation, rising from 1.5to 3-fold when compared to cells expressing wild type receptor (Gromoll et al., 1996). Other studies reported that the corresponding $D$ to $G$ mutation has occurred in the thyroid stimulating hormone receptor and luteinizing hormone receptor (Laue et al., 1995; Tonacchera et al., 1996). Inactivating homozygous A189V missense mutation in the FSHR was identified in about one-third of all Finnish XX ovarian failure (XXOF) patients (Aittomaki et al., 1995; Layman and McDonough, 2000). cAMP production was drastically reduced in immortalized MSC-1 cells in response to recombinant FSH. Another inactivating mutation of the FSHR gene was found at position 191 (N191I) in a healthy fertile woman and completely abolished the increase of cAMP production in response to FSH (Gromoll et al., 1995). These findings demonstrate that the number of functional receptor expressed on the cell surface is drastically reduced in these mutants, and that signal transduction is impaired as a result.

In the present study, we identified a novel constitutively activating mutant receptor, FSHR D540G, that resulted in highly increased cAMP production in the absence of eel FSH stimulation. Transfection of $5 \mu \mathrm{g}$ of D $540 \mathrm{G}$ mutant receptor resulted in a 19.6-fold increase in basal cAMP production in the absence of agonist when compared to cells expressing the wild type receptor. Future studies will provide insight into cell specific elements that are involved in gonadotropin receptor signal transduction during eel maturation.

\section{CONFLICTS OF INTEREST}

No potential conflict of interest relevant to this article was reported.

\section{ACKNOWLEDGEMENTS}

This research was financially supported by the Korean Research Foundation program (2018R1A2B6007794), Republic of Korea.

\section{AUTHOR'S AFFILIATION, POSITION AND ORCID NO.}

JS Kim. Hankyong Nat'l Univ., Researcher, https://orcid.org/0000-0003-0851-3508

M Byambaragchaa. Hankyong Nat'l Univ., Postdoc, https://orcid.org/0000-0002-0277-1816

KS Min. Hankyong Nat'l Univ., Professor, https://orcid.org/0000-0002-5451-3085

\section{REFERENCES}

Aittomaki K, Lucena JLD and Pakarinen P. 1995. Mutation in the follicle-stimulating hormone receptor gene causes hereditary hypergonadotropic hypogonadism. Cell. 82:959968. 
Bae F, Pescovitz OH and Steinmetz R. 2009. No activating mutations of FSH receptor in four children with ovarian juvenile granulosa cells tumors and the association of these tumors with central precocious puberty. J Pediatr Adolesc Gyneco. 22:173-179.

Beau I, Touraine P, Meduri G, Gougeon A, Desroches A, Matuchansky C, Milgrom E, Kuttenn F and Misrahi M. 1998. A novel phenotype related to partial loss of function mutations of the follicle stimulating hormone receptor. J Clin Invest. 102:1352-1359.

Bramble MS, Goldstein EH, Lipson A, Ngun T, Eskin A, Gosschalk JE, Roach L, Vashist N, Barseghyan H, Lee E, Arboleda VA, Vaiman D, Yuksel Z, Fellous M and Vilain E. 2016. A novel follicle-stimulating hormone receptor mutation causing primary ovarian failure: a fertility application of whole exome sequencing. Human Reproduction. 31:905-914.

Byambarachaa M, Kim DJ, Kang MH and Min KS. 2018a. Site specificity of eel luteinizing hormone N-linked oligosaccharides in signal transduction. Gen Comp Endocrinol. 268:5056.

Byambarachaa M, Lee SY, Kim DJ, Kang MH and Min KS. 2018b. Signal transduction of eel luteinizing hormone receptor (eelLHR) and follicle stimulating hormone receptor (eelFSHR) by recombinant equine chorionic gonadotropin (rec-eCG) and native eCG. Dev Reprod. 22:55-63.

Fragoso MC, Latronico AC, Carvalho FM, Zerbini MC, Marcondes JA, Araujo LM, Lando VS, FrazzattoET, Mendonca BB and Villares SM. 1998. Activating mutation of the stimulatory $\mathrm{G}$ protein as a putative cause of ovarian and testicular human stromal Leydig cell tumors. J Clin Endocinol Metab. 83:2074-2078.

Ghezelayagh Z, Totonchi M, Zarei-Moradi S, Asadpour O, Maroufizadeh S, Eftekhari-Yazdi E, Gourabi H and MohseniMeybodi A. 2016. The impact of genetic variation and gene expression of the follicle-stimulating hormone receptor on ovarian reserve. Cell J. 19:620-626.

Gromoll J, Simoni M, Nordhoff V, Behre HM, De Geyter C and Nieschlag E. 1995. Functional and clinical consequences of mutations in the FSH receptor. Mol Cell Endocrinol. 125:177-182.

Gromoll J, Simoni M and Nieschlag E. 1996. An activating mutation of the follicle-stimulating hormone receptor autonomously sustains spematogenesis in a hypophysectomized man. J Clin Endocrinol Metab. 81:1367-1370.

Katari S, Wood-Trageser MA, Jiang H, Kalynchuk E, Muzumdar R, Yatsenko SA and Rajkovic A. 2015. Novel inactivating mutation of the FSH receptor in two siblings of indian origin with premature ovarian failure. J Clin Endocrinol Metab. 100:2154-2157.

Kim DJ, Park CW, Byambaragchaa M, Kim SK, Lee BI, Hwang HK, Myeong JL, Hong SM, Kang MH and Min KS. 2016a. Data on the characterization of follicle-stimulating hormone monoclonal antibodies and localization in Japanese eel pituitary. Data Brief. 8:404-410.
Kim DJ, Park CW, Kim DW, Park HK, Byambaragchaa M, Lee NS, Hong SM, Seo MY, Kang MH and Min KS. 2016b. Production and characterization of monoclonal antibodies against recombinant tethered follicle-stimulating hormone from Japanese eel anguilla japonica. Gen Comp Endocrinol. 233:8-15.

Kim JM, Munkhuu O, Byambaragchaa M, Lee BI, Kim SK, Kang MH, Kim DH and Min KS. 2019. Site-specific roles of Nlinked oligosaccharides in recombinant eel follicle-stimulating hormone for secretion and signal transduction. Gen Comp Endocrinol. 276: 37-44.

Laue L, Chan WY, Hsueh A, Kudo M, Hsu SY and Wu SM. 1995. Genetic heterogeneity of constitutively activating mutations of the human luteinizing hormone receptor in familial male-limited precocious puberty. Proc Natl Acad Sci USA. 92:1906-1910.

Layman LC and McDonough PG. 2000. Mutations of follicle stimulating hormone- $\beta$ and its receptor in human and mouse: genotype/phenotype. Mol Cell Endocrinol. 161:917.

Lee SY, Byambaragchaa M, Kim JS, Seong HK, Kang MH and Min KS. 2017. Biochemical characterization of recombinant equine chorionic gonadotropin (rec-eCG), using $\mathrm{CHO}$ cells and pathHunter parental cells expressing equine luteinizing hormone/chorionic gonadotropin receptors (eLH/CGR). J Life Sci. 27:864-872.

Liu H, Xu X, Han T, Yan L, Cheng L, Qin Y, Liu W, Zhao S and Chen Z. 2017. A novel homozygous mutation in the FSHR gene is causative for primary ovarian insufficiency. Fertility and Sterility. 108:1050-1055.

Min KS, Hiyama T, Seong HH, Hattori N, Tanaka S and Shiota K. 2004. Biological activities of tethered equine chorionic gonadotropin (eCG) and its deglycosylated mutants. J Reprod Dev. 50:297-304.

Nakano R, Kitayama S and Yamato M. 1989. Localization of gonadotropin binding sites in human ovarian neoplasms. Am J Obstet Gynecol. 161:905.

Simoni M, Gromoll J and Nieschlag E. 1997. The follicle-stimulating hormone receptor: biochemistry, molecular biology, physiology, and pathophysiology. Endocrine Reviews. 18:739-771.

Simoni M and Nieschlag E. 1995. FSH in therapy: physiological basis, new preparations and clinical use. Reprod Med Rev. 4:163-177.

Stouffer RL, Grodin MS, Davis JR and Surwit EA. 1984. Investigation of binding sites for follicle-stimulating hormone and chorionic gonadotropin in human ovarian cnacers. J Clin Endocrinol Metab. 59:441-446.

Tapanainen JS, Aittomaki K, Min J, Vaskivuo T and Huhtaniemi IT. 1997. Men homozygous for an inactivating mutations of the follicle-stimulating hormone receptor gene present variable suppression of spermatogenesis and fertility. Nat Genet. 15:205-206. 